\title{
Viral Respiratory Infections in Young Children Attending Day Care in Urban Northeast Brazil
}

\author{
Leda Solano de Freitas Souza, MD, PhD, ${ }^{1 *}$ Eduardo Antônio Gonçalves Ramos, MD, PhD, ${ }^{2}$ \\ Fernando Martins Carvalho, MD, PhD, ${ }^{1}$ Virgínia Maria Castro Ribeiro Guedes, MD, ${ }^{1}$ \\ Lídia Silva Souza, MD, ${ }^{1}$ Cristiane Machado Rocha, MD, ${ }^{1}$ Andréa Barreto Soares, MD, ${ }^{1}$ \\ Luciana de Freitas Velloso, ${ }^{\mathrm{MD}},{ }^{1}$ Izolete Santos Macedo, $\mathrm{MSc}^{3}{ }^{3}$ \\ Fernanda Edna Araujo Moura, MD, ${ }^{2}$ Marilda Siqueira, PhD, ${ }^{4}$ Silvana Fortes, ${ }^{4}$ \\ Cibele Cruz de Jesus, ${ }^{2}$ Christiane Maria Gaspar Santiago, ${ }^{2}$ \\ Ana Maria da Silva Carvalho, ${ }^{2}$ and Eurico Arruda, $\mathrm{MD}, \mathrm{PhD}^{3}$
}

\begin{abstract}
Summary. A cohort of children attending a day care center in Salvador (Bahia, Brazil) was studied prospectively to determine the incidence of viral respiratory infectious episodes and to identify the viruses associated with them. Two hundred seventy-one nasopharyngeal samples were collected over a 1-year period for examination, using indirect immunofluorescence with monoclonal antibodies against adenovirus, influenza $A$ and $B$, parainfluenzae $1-3$, and respiratory syncytial virus, and reverse transcriptase-polymerase chain reaction for picornavirus.

Examination yielded positive results in 116 samples (42.8\%). Rhinovirus was identified alone in 56 samples (48.3\%) and was observed along with other viruses in 11 additional samples. Incidence density of viral respiratory infectious episodes was 7.66 episodes $/ 1,000$ child-days.

Pediatr Pulmonol. 2003; 35:184-191. ๑ 2003 Wiley-Liss, Inc.
\end{abstract}

Key words: acute respiratory infections; viral respiratory infections; rhinovirus; day care center; infants; epidemiology; wheezing.

\section{INTRODUCTION}

Acute respiratory infections (ARI) are prevalent worldwide, and rival diarrhea as the leading cause of death in children less than 1 year old in developing countries. ${ }^{1,2}$ Several community-based studies have established the importance of common viral ARI in tropical countries. ${ }^{3}$

Providing suitable day care for young children has become an important economic issue, especially in developing nations, where mothers from underprivileged classes join the work force to contribute to the family income. Some studies have shown that attending day care can be a risk factor for respiratory diseases in young children. ${ }^{4-8}$ Therefore, it is relevant to carry out studies on the etiology of ARI in day care facilities which constitute probably the most favorable environment for the transmission of common respiratory viruses among assembled susceptible hosts. Surprisingly, studies on the viral etiologies of ARI in children attending day care are relatively few in the indexed literature. ${ }^{9-11}$ The institution of possible interventions for the prevention of ARI in day care children in tropical areas will depend on assessing the frequency, etiologies, and seasonality of these infections.

We shall report results of a day care-based ARI study, carried out over a 12-month period to determine the frequency, seasonality, and certain clinical features of (c) 2003 Wiley-Liss, Inc. common viral ARI in children younger than 2 years old in Salvador, Bahia, Northeast Brazil.

\footnotetext{
${ }^{1}$ Department of Pediatrics and Department of Preventive Medicine, Faculty
} of Medicine Federal University of Bahia, Salvador, Bahia, Brazil.

${ }^{2}$ Gonçalo Moniz Research Center, Oswaldo Cruz Foundation, Salvador, Bahia, Brazil.

${ }^{3}$ Virology Laboratory, Department of Cell and Molecular Biology, University of São Paulo School of Medicine, Ribeirão Preto, São Paulo, Brazil.

${ }^{4}$ Oswaldo Cruz Foundation, Rio de Janeiro, Brazil.

Grant sponsor: FAPESP; Grant sponsor: FIOCRUZ and PAPES Program and CPGM; Grant sponsor: CNPq.

*Correspondence to: Leda Solano de Freitas Souza, M.D., Ph.D., Rua Ernesto de Melo Jr 79, Pituba 41820-060, Salvador, Bahia, Brazil.

E-mail: ledasolano@bol.com.br

Received 19 February 2001; Accepted 12 April 2002.

DOI 10.1002/ppul.10194

Published online in Wiley InterScience (www.interscience.wiley.com). 


\section{MATERIALS AND METHODS}

\section{Study Design and Population}

A longitudinal, prospective study of ARI episodes in a cohort of children attending a day care center was performed. The study was carried out in a day care center for children of low-income families in Salvador, the capital city of the state of Bahia, Northeast Brazil. Salvador is a city of 2.5 million inhabitants at sea level, $13^{\circ}$ south of the equator. The climate is tropical with high relative humidity $(>70 \%)$, rainfall throughout the year with a peak in April, and drier months in December and January. The temperature varies between $21-35^{\circ} \mathrm{C}$.

The day care center houses up to 150 children aged 2 months to 4 years old in a floor space of $450 \mathrm{~m}^{2}$. The children stay in the day care center from 7 AM to 6 PM, Monday through Friday. There are six well-ventilated $46-\mathrm{m}^{2}$ rooms with approximately 25 cots in each of them; 3 recreational areas where children are placed according to age; and a common dinning room. Smoking is prohibited. Two caretakers are in charge of each group of 20 children. Institutional policy does not exclude ill children from care, but when they have fever or dyspnea, they are kept in a separate ward where they are evaluated and treated by a pediatrician and a nurse. Therefore, most of the ill children are allowed to stay, whereas the more severely ill are sent to a hospital. Usually, children come to the day care center even when they are ill, because of the availability of medical assistance there and because their mothers work and cannot take care of them at home. All attending children aged 2-24 months were enrolled in the study. Children were excluded from the cohort when they were older than 24 months or when they stopped attending the facility, which occurred for different reasons, such as lack of adaptation or because the family moved to other parts of the city, far away from the center. All children newly admitted to the day care center were

\begin{tabular}{|ll|}
\hline \multicolumn{2}{|l|}{ ABBREVIATIONS } \\
ARI & Acute respiratory infections \\
Av & Adenovirus \\
Ev & Enterovirus \\
FIOCRUZ & Oswaldo Cruz Institute Foundation \\
Hep 2 & Cell line derived from laryngeal carcinoma \\
Flu A & Influenza A virus \\
Flu B & Influenza B virus \\
MDCK & Mardin-Darby canine kidney cells \\
NPA & Nasopharyngeal aspirate \\
PBS & Phosphate-buffered saline \\
PCR & Polymerase chain reaction \\
Pflu 2 & Parainfluenza type 2 virus \\
Pflu 3 & Parainfluenza type 3 virus \\
RSV & Respiratory syncytial virus \\
RT-PCR & Reverse transcriptase polymerase chain reaction \\
Rv & Human rhinovirus \\
VTM & Viral transport medium \\
\hline
\end{tabular}

included, so that the number of enrolled children was kept fairly constant (Table 1). The day care center was closed for summer vacation in January and February. The study protocol was approved by the review board of the Federal University of Bahia. Parents as guardians gave verbal informed consent for nasopharyngeal sample collections.

\section{Surveillance}

Clinical surveillance was conducted three times per week, from May 1996 through April 1997 by pediatricians who performed physical examinations on all enrolled children. The judgment of the mother or guardian about the health of the child as expressed at the time the child was brought in each day was recorded. A child was considered ill when either the mother or a pediatrician reported the presence of one or more respiratory symptoms. The symptoms considered were: rhinorrhea, sneezing, nasal obstruction, hoarseness, stridor, cough, dyspnea, tachypnea, chest retraction, wheezing, rhonchi, or rales on auscultation of the chest. An episode of respiratory infection was defined by the presence of one or more of the above respiratory symptoms, preceded by at least 7 symptom-free days. The attack rate was expressed as ARI episodes per 1,000 child-days at risk. A child-day was considered as 1 day of study for each child in the cohort. Therefore, the study was comprised of the number of child-days that was equal to the sum of children observed per study day, times the total number of study days.

\section{Sampling}

Nasopharyngeal secretions were collected when children started having respiratory symptoms, with or without fever. Some children with perennial respiratory symptoms without obvious exacerbations were also selected for sampling, excluding those who had nasopharyngeal sampling in the previous 15 days. This selection was done at random, observing the need to include roughly equivalent numbers of children from all age categories: 2 6 months, 7-12 months, and 13-24 months. Nasopharyngeal aspirates (NPA) were collected from children with five different types of respiratory illness episodes: Type I, children selected among those with perennial respiratory symptoms; Type II, all children with acute upper airway symptoms without fever; Type III, all children with acute lower airway symptoms without fever; Type IV, all children with upper airway symptoms and fever; and Type V, all children with lower airway symptoms and fever. Nasopharyngeal secretions were suctioned with a 20-mL syringe into a disposable urethral catheter (gauge 6 or 8) placed in the nasopharynx. The ensemble containing the sample was kept on ice and taken to the virology laboratory at FIOCRUZ (Salvador, Bahia) within $1 \mathrm{hr}$ of collection. 
TABLE 1-Number of Children in Cohort During Acute Respiratory Infection Study (Salvador, Bahia, Brazil, 1996-1997)

\begin{tabular}{|c|c|c|c|}
\hline Months & $\begin{array}{c}\text { Number of children } \\
\text { newly enrolled }\end{array}$ & $\begin{array}{c}\text { Number of children } \\
\text { in cohort }\end{array}$ & $\begin{array}{l}\text { Number of } \\
\text { withdrawals }\end{array}$ \\
\hline May 1996 & 55 & 55 & 2 \\
\hline June 1996 & 9 & 62 & 2 \\
\hline July 1996 & 12 & 72 & 7 \\
\hline August 1996 & 10 & 75 & 8 \\
\hline September 1996 & 8 & 75 & 13 \\
\hline October 1996 & 2 & 64 & 2 \\
\hline November 1996 & 1 & 63 & 1 \\
\hline December 1996 & 1 & 63 & 63 \\
\hline March 1997 & 62 & 62 & 5 \\
\hline April 1997 & 17 & 74 & 2 \\
\hline
\end{tabular}

\section{Virus Detection}

In the laboratory, $0.5 \mathrm{~mL}$ of NPA was put in a tube with viral transport medium (VTM) containing streptomycin and fungizone. After $6 \mathrm{hr}, 0.2 \mathrm{~mL}$ of the secretion in VTM were inoculated onto Hep-2 and/or Mardin-Darby canine kidney cell (MDCK) monolayers prepared in 16-mm tubes. Monolayers were incubated at $37^{\circ} \mathrm{C}$, and examined every other day for cytopathic effect; hemadsorption was performed on MDCK cells on the seventh day. Positive cultures were tested by indirect immunofluorescence. The remaining NPA in VTM was snap-frozen, kept at $-70^{\circ} \mathrm{C}$, and sent to the University of São Paulo School of Medicine (Ribeirão Preto, São Paulo, Brazil) for testing for picornaviruses by reverse transcriptase-polymerase chain reaction (RT-PCR) and hybridization, as previously described. ${ }^{12,13}$

Adenovirus positive cultures were frozen $\left(-70^{\circ} \mathrm{C}\right)$ and later sent to FIOCRUZ in Rio de Janeiro for serotyping by neutralization. ${ }^{14}$ The remaining sample was transferred to a tube containing phosphate-buffered saline (PBS) and centrifuged at $450 \times g$. The cell pellet was resuspended in PBS and slides were prepared, air-dried, and fixed in acetone for $10 \mathrm{~min}$. Indirect immunofluorescence was performed with a pool of monoclonal antibodies (Chemicon) against respiratory syncytial virus (RSV), influenza A and B (Flu A and Flu B), parainfluenza 1, 2, and 3 (Pflu 1, 2, and 3), and adenovirus (AV). Samples positive by this screening method were tested with antibodies from the same manufacturer specific for each of the individual viruses.

\section{RESULTS}

On average, 63 children aged 2-24 months were in the cohort throughout the study period. By the end of the study, 138 children had been in the cohort for a period of time varying from 1-291 days. At enrollment, children's ages varied from 66-572 days. The length of time of day care attendance prior to enrollment was equal to or less than 60 days for $106(77 \%)$ of the 138 children. The remaining had been in attendance for 61-448 days.

The study comprised 16,855 child-days of observation. Respiratory symptoms were recorded on 12,515 (74\%) child-days, and 429 episodes of respiratory illnesses were recorded, for an attack rate of 98.8 episodes $/ 1,000$ childdays. The attack rate is expressed as incidence density, which was calculated from the ratio between the number of respiratory disease episodes (429) and the number of days at risk for respiratory disease (4,340 child-days without respiratory symptoms). One hundred and seven children (79.3\%) had persistent respiratory illness, expressed mainly by continuously present runny nose; among those children, 94 also had acute episodes, defined by the presence of additional symptoms that characterized exacerbations, and 13 had only chronic symptoms. Twenty-eight children (20.7\%) had only acute episodes of respiratory disease, without perennial symptoms, and 3 children did not show any respiratory symptoms all through the study. Most of the respiratory infectious episodes were mild or moderately severe. One child had severe pneumonia and abandoned the day care. No difference in duration of ARI episodes by age group was observed.

A total of 271 specimens was collected from 106 children throughout the study. Of those, $61(22 \%)$ were from Type I episodes; 45 (17\%) from Type II; 66 (24\%) from Type III; 62 (23\%) from Type IV; and 37 (14\%) from Type V. All 271 collected samples were examined by indirect immunofluorescence, yielding 43 (16\%) positive results. Of 264 samples available for testing by RT-PCR and hybridization, $86(33 \%)$ were positive for a picornavirus; 67 (78\%) were rhinovirus (Rv)-positive; and 19 (22\%) were enterovirus-positive.

Of the 271 samples tested, $116(43 \%)$ were positive for some virus (Table 2), for a total of 129 virus identifications: $67(52 \%)$ rhinoviruses; $19(15 \%)$ enteroviruses (Ev); $16(12 \%)$ adenoviruses; $14(11 \%)$ parainfluenza viruses (13 type 3 and 1 type 2); 8 (6\%) influenza viruses 
TABLE 2-Viruses Identified in 116 Nasopharyngeal Samples From Children in a Day Care Center in Relation to Children's Clinical Status (Salvador, Bahia, Brazil, 1996-1997) ${ }^{1}$

\begin{tabular}{|c|c|c|c|c|c|c|c|c|c|c|c|c|}
\hline & \multicolumn{2}{|c|}{$\mathrm{I}(\mathrm{n}=61)^{2}$} & \multicolumn{2}{|c|}{ II $(\mathrm{n}=45)^{2}$} & \multicolumn{2}{|c|}{ III $(n=66)^{2}$} & \multicolumn{2}{|c|}{$\mathrm{IV}(\mathrm{n}=62)^{2}$} & \multicolumn{2}{|c|}{$\mathrm{V}(\mathrm{n}=37)^{2}$} & \multicolumn{2}{|c|}{ Total $(\mathrm{n}=271)$} \\
\hline & $\mathrm{n}$ & $\%$ & $\mathrm{n}$ & $\%$ & $\mathrm{n}$ & $\%$ & $\mathrm{n}$ & $\%$ & $\mathrm{n}$ & $\%$ & $\mathrm{n}$ & $\%$ \\
\hline $\mathrm{Rv}$ & 14 & 66.7 & 13 & 81.2 & 8 & 34.8 & 12 & 40.0 & 9 & 34.6 & 56 & 48.3 \\
\hline $\mathrm{Ev}$ & 5 & 23.8 & 1 & 6.2 & 5 & 21.7 & 4 & 13.3 & 2 & 7.7 & 17 & 14.6 \\
\hline Pflu 3 & 0 & & 0 & & 3 & 13.0 & 2 & 6.7 & 5 & 19.2 & 10 & 8.6 \\
\hline $\mathrm{Av}$ & 1 & 4.8 & 0 & & 2 & 8.7 & 4 & 13.3 & 2 & 7.7 & 9 & 7.7 \\
\hline Flu A & 0 & & 1 & 6.2 & 0 & & 2 & 6.7 & 3 & 11.5 & 6 & 5.2 \\
\hline$A v+R v$ & 0 & & 0 & & 1 & 4.4 & 2 & 6.7 & 3 & 11.5 & 6 & 5.2 \\
\hline RSV & 0 & & 0 & & 2 & 8.7 & 1 & 3.3 & 0 & & 3 & 2.5 \\
\hline $\mathrm{RSV}+\mathrm{Rv}$ & 0 & & 1 & 6.2 & 0 & & 0 & & 1 & 3.9 & 2 & 1.7 \\
\hline Pflu $3+$ Rv & 0 & & 0 & & 2 & 8.7 & 0 & & 0 & & 2 & 1.7 \\
\hline Flu B & 0 & & 0 & & 0 & & 1 & 3.3 & 0 & & 1 & 0.9 \\
\hline Pflu 2 & 0 & & 0 & & 0 & & 1 & 3.3 & 0 & & 1 & 0.9 \\
\hline $\mathrm{Av}+\mathrm{Ev}$ & 1 & 4.8 & 0 & & 0 & & 0 & & 0 & & 1 & 0.9 \\
\hline Pflu $3+$ Ev & 0 & & 0 & & 0 & & 1 & 3.3 & 0 & & 1 & 0.9 \\
\hline Flu A + Rv & 0 & & 0 & & 0 & & 0 & & 1 & 3.9 & 1 & 0.9 \\
\hline Total & 21 & 100.0 & 16 & 100.0 & 23 & 100.0 & 30 & 100.0 & 26 & 100.0 & 116 & 100.0 \\
\hline
\end{tabular}

${ }^{1}$ Rv, rhinovirus; Ev, enterovirus; Flu, influenza virus (A and B); Pflu, parainfluenza virus (2 and 3); Av, adenovirus; RSV, respiratory syncytial virus. ${ }^{2}$ See text for details; refers to clinical status at time of enrollment. $n=$ number of samples tested.

(7 type A and 1 type B); and 5 (4\%) respiratory syncytial viruses (RSV).

Thirteen samples were positive for two viruses (Table 2). Only 154 of the 271 samples collected were inoculated in cell cultures, yielding $17(11 \%)$ viral isolates. Of the 116 cases of ARI for which a viral etiology was established, 73 were diagnosed by polymerase chain reaction (PCR), 30 by immunofluorescence, and the 13 that were positive for two viruses were detected by both methods. The 17 samples from which a virus was isolated in cell culture yielded Av (11 samples), Pflu 3 (4 samples), and RSV ( 2 samples), and were also positive by immunofluorescence. All Av isolated were serotyped by neutralization, and all of them were Type 2 .

Rhinoviruses were detected more frequently during the autumn months, but occurred throughout the studied period, showing a lower frequency only in November and December. Pflu 3 occurred as a small outbreak in October and November. RSV was detected only in March and May (autumn). The other viruses did not exhibit any seasonality (Fig. 1A,B).

Most episodes of diagnosed viral respiratory infections occurred in children aged between 3-9 months (Table 3). In this age group, 181 samples were collected, yielding $74(40.9 \%)$ positive results. Among children belonging to other age groups, 85 samples were collected with 40 (47.1\%) positive results. Most Rv detections occurred in children younger than 6 months; they were slightly less frequent in children 6-12 months old and increased again in those older than 12 months; Rv was detected significantly more frequently than all other respiratory viruses taken together (Fig. 2).
Episodes of confirmed viral ARI had a mean duration of 15 days and occurred with an attack rate of 7.66 episodes/ 1,000 child-days of observation (incidence density, 116 episodes/15,151 child-days at risk for viral ARI). Table 2 contains a summary of results according to clinical category. All 56 episodes of $\mathrm{Rv}$ infections were characterized by presence of upper airways symptoms, with concurrent lower airways symptoms present in $31(55 \%)$. Wheezing was found in $16(29 \%)$ and fever in $23(41 \%)$ episodes of rhinovirus ARI. Upper airways symptoms were observed in 14 of 17 episodes of Ev infection, lower airway symptoms in 8 , wheezing in 5 , and fever in 6 . Among the 10 episodes of infection caused by Pflu 3, upper airway symptoms were observed in 7 , lower airway symptoms in 8 , wheezing in 4 , and fever in 7. All 9 episodes of Av infections presented with upper airway symptoms, and 4 of them had also lower airway symptoms, with wheezing present in 1 and fever in 5. Five of the 6 Flu A episodes had upper airway symptoms, 2 of them had lower airway symptoms with no wheezing, and 4 had fever.

Wheezing was observed in $32(27.6 \%)$ of all 116 documented viral ARI episodes and in $30(19.3 \%)$ of the 155 cases of ARI with no virus detected. Conversely, NPA was performed in a total of 62 wheezing episodes, and a virus was detected in 32 (51.6\%): $\mathrm{Rv}$ alone in 14 (43.7\%); Ev alone in 5 (15.6\%); Pflu 3 alone in 4 (12.5\%); RSV alone in 2 (6.2\%); an association of Av with $\mathrm{Rv}$ in 3 (9.4\%); an association of Pflu 3 with Rv in $2(6.2 \%)$; Av alone in $1(3.1 \%)$; and an association of RSV with $\mathrm{Rv}$ in $1(3.1 \%)$. The 62 wheezing episodes were distributed in all age groups: $26(41.9 \%)$ such episodes 
A

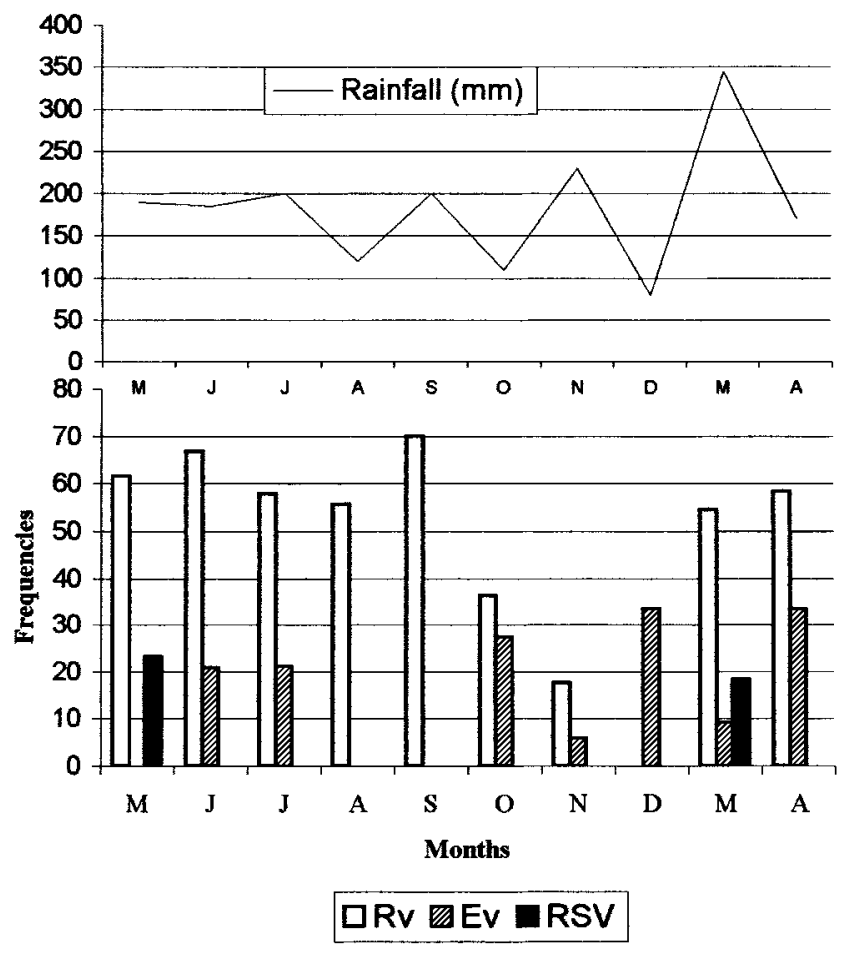

B

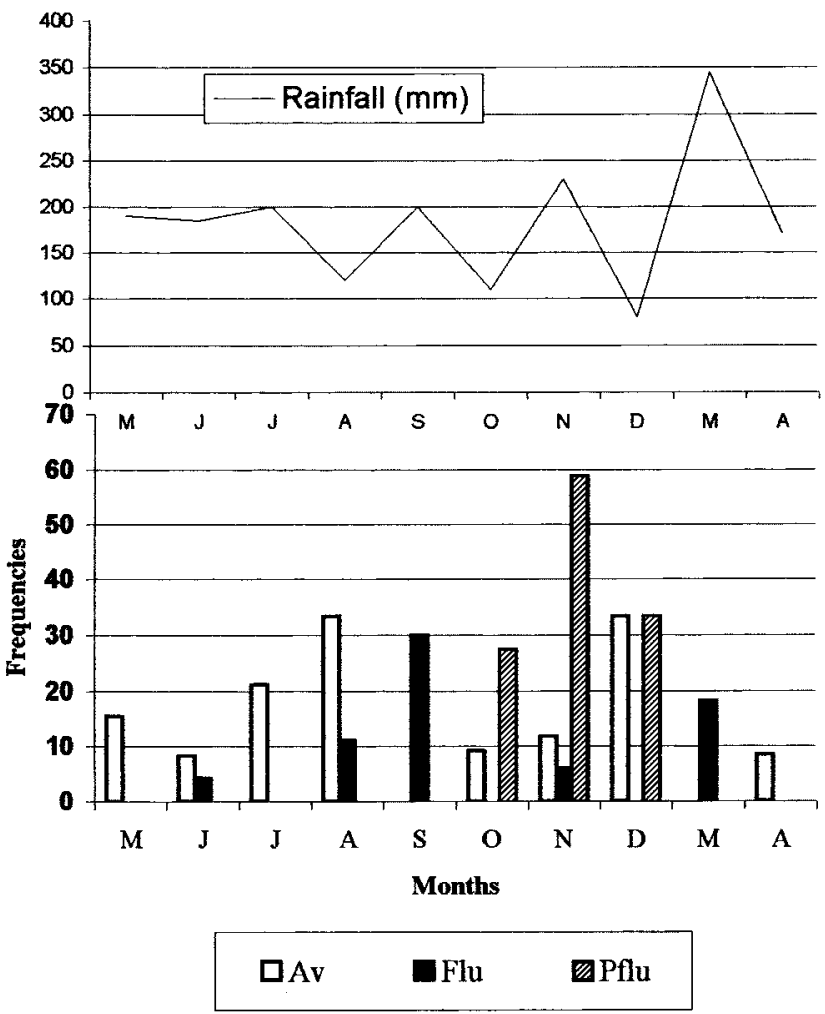

Fig. 1. A: Frequencies (\%) of rhinovirus (Rv), enterovirus (Ev), and respiratory syncytial virus (RSV), in relation to total number of positive results per month, in children attending a day care center (Salvador, Bahia, Brazil, 1996-1997). The day care center was closed in January and February. B: Frequencies (\%) of adenovirus (Av), influenza (Flu), and parainfluenza (Pflu) viruses, in relation to total number of positive results per month, in children attending a day care center (Salvador, Bahia, Brazil, 1996-1997). The day care center was closed in January and February.

occurred in the 2-6-month-old group; $20(32.3 \%)$ in the 7-12-month-old group; and $16(25.8 \%)$ in the $13-$ 24 -month-old age group. Considering the 32 virusassociated wheezing episodes, $15(46.9 \%)$ occurred in 2-6-month-old children; 9 (28.1\%) in 7-12-month-old children; and $8(25 \%)$ in 13-24-month-old children. Rhinovirus accounted for $13(86.7 \%)$ of the 15 wheezing episodes in 2-6-month-old infants; for $2(22.2 \%)$ of the 9 wheezing episodes in the 7-12-month-old group; and for $5(62.5 \%)$ of the 8 wheezing episodes in the $13-$ 24-month-old group.

\section{DISCUSSION}

This study found a high incidence of respiratory illnesses in children aged 2-24 months, attending a day care center for low-income children. The attack rate of 98.8 episodes/1,000 child-days indicates that this kind of facility constitutes an environment highly favorable for maintaining transmission of common respiratory pathogens. In community-based studies, much lower figures have been reported: 3.6 episodes/1,000 child-days in São Paulo, Brazil, in 1986; ${ }^{15} 6.4$ episodes/1,000 childdays in Rio de Janeiro, Brazil; ${ }^{16} 18.08$ episodes/1,000 child-days in Colombia; ${ }^{17}$ and 16.7 episodes/1,000 childdays in the Phillipines. ${ }^{18}$ Data on ARI incidence in day care facilities are scarce in the indexed literature, but several studies have shown the role of these facilities as risk factors for respiratory illnesses. ${ }^{4-9,19,20}$ To the best of our knowledge, this is the most extensive prospective study of viral respiratory infections in children from socioeconomically underprivileged families attending day care in Brazil.

The proportion of virus-positive episodes in this study was $42.8 \%$. This rate is higher than that obtained in a household-based study of children from similar social strata in another large city of Northeast Brazil. ${ }^{21}$ This is likely a true account of the great circulation of viruses that must occur in crowded conditions such as can be found in an understaffed day care facility, with a large number of infants and toddlers who exchange respiratory secretions continuously. But this virus detection rate may also be a 
TABLE 3-Number of Positive Samples According to Age and Total Number of Collected Samples (Salvador, Bahia, Brazil, 1996-1997)

\begin{tabular}{lcc}
\hline $\begin{array}{l}\text { Ages } \\
\text { (months) }\end{array}$ & $\begin{array}{c}\text { Number of collected } \\
\text { samples }\end{array}$ & $\begin{array}{c}\text { Number (and percentage) } \\
\text { of positive samples }\end{array}$ \\
\hline 2 & 3 & $2(67 \%)$ \\
3 & 19 & $6(30 \%)$ \\
4 & 28 & $12(43 \%)$ \\
5 & 36 & $14(39 \%)$ \\
6 & 28 & $13(46 \%)$ \\
7 & 27 & $12(44 \%)$ \\
8 & 20 & $8(40 \%)$ \\
9 & 23 & $9(39 \%)$ \\
10 & 12 & $8(67 \%)$ \\
11 & 9 & $5(55 \%)$ \\
12 & 9 & $3(33 \%)$ \\
13 & 11 & $5(45 \%)$ \\
14 & 9 & $4(44 \%)$ \\
15 & 9 & $6(67 \%)$ \\
16 & 11 & $4(36 \%)$ \\
17 & 7 & $2(28 \%)$ \\
18 & 6 & $1(17 \%)$ \\
19 & 2 & $2(100 \%)$ \\
20 & 0 & 0 \\
21 & 1 & 0 \\
22 & 0 & 0 \\
23 & 0 & 0 \\
24 & 1 & 0 \\
Total & 271 & $116(43 \%)$ \\
\hline & &
\end{tabular}

consequence of the high sensitivity of the picornavirus RT-PCR, which has already been demonstrated in adults with colds. ${ }^{12}$ More recently, this test has enabled us to evaluate the actual impact of $\mathrm{Rv}$ as a cause of common respiratory illnesses in children and adults. ${ }^{13,22-24}$ In the present study, Rv was detected in 67 samples, which

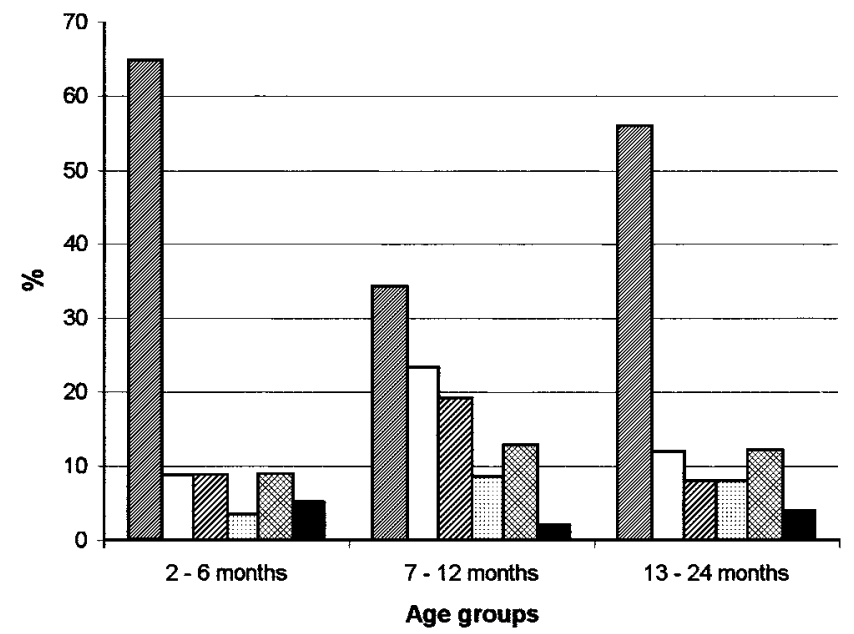

Rv aEv

Fig. 2. Frequencies of each respiratory virus identified in day care children in relation to number of positive results, in three age groups (Salvador, Bhaia, Brazil, 1996-1997). represented approximately $52 \%$ of the 129 positive samples obtained, a proportion that is in keeping with a previous household-based study conducted in northeast Brazil, which found $46 \%$ rhinoviruses by cell culture. ${ }^{21}$ Most published ARI community-based studies have not included adequate methods for the detection of Rv, and it has become clear that such studies may not account for the real importance of these viruses as causes of ARI in the community.

In the present study, RSV was detected in only 5 specimens, an unexpected low frequency. This low circulation of RSV is in keeping with previous findings of a household-based study in Fortaleza, another large urban coastal area located in northeast Brazil. ${ }^{21}$ However, this is in contrast to several other reports of high frequency of RSV in small children in different parts of the world, mostly found by hospital-based ARI studies, ${ }^{25-33}$ which carry the selection bias of sampling more severe cases. For example, in Salvador, a previous hospital-based study conducted from 1993-1996, with collection of nasopharyngeal aspirates from children less than 5 years old in emergency rooms and on pediatric wards, found that RSV was the most frequently identified virus. ${ }^{34,35}$ Other hospital-based studies in Brazil came up with similar results. ${ }^{36-44}$ The hospital-based study in Salvador used the same virologic laboratory (FIOCRUZ) and the same diagnostic techniques used in the present study. This reduces chances of lower diagnostic sensitivity for RSV in the day care samples. A limited ability of our tests to detect RSV is unlikely to be responsible for this low RSV detection, since we used a well-standardized, commercially available anti-RSV antibody in the immunofluorescence assay, done on fresh samples, with appropriate positive and negative controls included in each run. A study performed in day care centers in France ${ }^{10}$ found RSV to be a frequent cause of ARI. More ARI studies in day care centers of tropical cities are needed in order to verify our findings with respect to the low frequency of RSV. In this regard, RT-PCR-based assays for RSV ${ }^{23}$ could potentially serve the purpose of assessing the true impact of this virus in future day care based studies.

In the present study, rhinovirus episodes were evenly distributed in the five clinical categories that were sampled. The other respiratory viruses (Pflu 3, Flu A, RSV, and Av) were detected in association with more severe episodes, characterized by fever and/or signs of lower airway involvement. In all clinical categories, however, Rv was the most frequently identified virus, reinforcing the importance of these agents in the etiology of respiratory illnesses in young children, including those with wheezing and other lower respiratory symptoms. The recently reported findings that Rv replicates in the lower respiratory tract ${ }^{45}$ highlights the potential impact that this virus may have as a cause of lower ARI which may have been neglected previously. Our findings confirmed the importance of 
viruses in association with wheezing episodes in young children, previously reported by many authors. ${ }^{46,47}$ The high frequency of rhinoviruses in association with wheezing should raise our awareness of the importance of these viruses in causing lower respiratory illness in young children in addition to RSV, whose association with wheezing has been documented largely in the Northern Hemisphere. ${ }^{24}$

Our findings highlight the great impact of respiratory illness in low-income children attending day care and, to the best of our knowledge, document for the first time the high frequency of rhinovirus as a cause of respiratory illness in young children in day care in a tropical urban area.

\section{REFERENCES}

1. Selwyn BJ. La epidemiología de la infección aguda del aparato respiratorio en niños pequeños. Comparación de los hallazgos de varios países en vías de desarollo. Rev Infect Dis [Suppl] 1990; 12:870-888.

2. McIntosh K, Halonen P, Ruuskanen O. Report of a workshop on respiratory viral infections: epidemiology, diagnosis, treatment and prevention. Clin Infect Dis 1993;16:151-164.

3. Arruda E, Geist FC, McAuliffe MI, Hayden FG. Viral respiratory tract illnesses in a developing tropical area. In: Guerrant RL, Souza MA, Nations MK, editors. At the edge of development. Health crises in a transitional society. Durham: Carolina Academic Press; 1996. p 203-223.

4. Marbury MC, Maldonado G, Waller L. Lower respiratory illness, recurrent wheezing and day care attendance. Am J Respir Crit Care Med 1997;155:156-161.

5. Low AM, Pereira MG. Morbidade em creche de Brasília. Estudo longitudinal de incidência de enfermidades no ano de 1977. Rev Saude Publica 1980;14:454-461.

6. Fleming DW, Cochi SL, Hightower AW, Broome CV. Childhood upper respiratory tract infections. To what degree is incidence affected by day care attendance? Pediatrics 1987;79:55-60

7. Anderson LJ, Parker RA, Strikas RA, Farrar JA, Gangarosa EJ, Keyserling HL, Sikes RK. Day-care center attendance and hospitalization for lower respiratory tract illness. Pediatrics 1988;82: 300-308.

8. Holberg CJ, Wright AL, Martinez FD, Morgan WJ, Taussig LM. Child day care, smoking by caregivers, and lower respiratory tract illness in the first 3 years of life. Group Health Medical Associates. Pediatrics 1993;91:885-892.

9. Klein JD, Collier AM, Glezen WP. An influenza B epidemic among children in day care. Pediatrics 1976;58:340-345.

10. Aymard M, Chomel JJ, Allard JP, Thouvenot D, Honegger D, Floret D, Boissel JP, Collet JP, Durr F, Gillet J. Epidemiology of viral infections and evaluation of the potential benefit of OM-85 $\mathrm{BV}$ on the virologic status of children attending day-care centers. Respiration [Suppl] 1994;61:24-31.

11. Loda FA, Glezen WP, Clyde WA Jr. Respiratory disease in group day care. Pediatrics 1972;49:428-437.

12. Arruda E, Pitkaranta A, Witek TJ Jr, Doyle CA, Hayden FG. Frequency and natural history of rhinovirus infections in adults during autumn. J Clin Microbiol 1997;35:2864-2868.

13. Pitkaranta A, Arruda E, Malmberg H, Hayden FG. Detection of rhinovirus in sinus brushings of patients with acute community acquired sinusitis by reverse transcription-PCR. J Clin Microbiol 1997;35:1791-1793.
14. Lennette EH, Schmidt NJ. Diagnostic procedures for viral, rickettsial and chlamydial infections. 5th ed. Washington, DC: American Public Health Association; 1979. p 246-247.

15. Barata RCB, Waldman EA, Moraes JC, Guibu IA, Rosov T, Takimoto $\mathrm{S}$. Gastroenterites e infecções respiratórias agudas em crianças menores de 5 anos, em área da região sudeste do Brasil, 1986-1987. I-Infecções respiratórias agudas. Rev Saude Publica 1996;30:553-563

16. Sutmoller F, Maia PR. Acute respiratory infecions in children living in two low-income communities of Rio de Janeiro, Brazil Mem Inst Oswaldo Cruz 1995;90:665-674.

17. Borrero I, Fajardo L, Bedoya A, Carmona F, de Borrero MF Infecciones agudas del aparato respiratorio en una cohorte natal de niños hasta 17 meses de vida (Cali, Colombia). Rev Infect Dis [Suppl] 1990;12:950-956.

18. Tupasi TE, de Leon LE, Lupisan S, Torres CU, Leonor ZA, Sunico MAS, Mangubat N, Miguel CA, Medalla F, Tan ST, Dayrit M. Patrones de infecciones respiratorias agudas en niñosun estudio longitudinal en una comunidad deprimida en Metro Manila. Rev Infect Dis [Suppl] 1990;12:940-949.

19. Correia L, Fonseca W, Barros A, Ross D. Frequência a creches como fator de risco para infecções respiratórias agudas e otite média, entre pré-escolares de Fortaleza (Epirio 98. Rio de Janeiro). In: Anais do $11^{\circ}$ Congresso Brasileiro de Epidemiologia: Comunicações Coordenadas 1998; 9, n 29.

20. Denny FW Jr. The clinical impact of human respiratory virus infections (Tenth Transatlantic Airway Conference-January 1995). Am J Respir Crit Care Med 1995;152:4-12.

21. de Arruda E, Hayden FG, McAuliffe JF, de Sousa MA, Mota SB, McAuliffe MI, Geist FC, Carvalho EP, Fernandes MC, Guerrant RI, Gwalthey JM Jr. Acute respiratory viral infections in ambulatory children of urban northeast Brazil. J Infect Dis 1991; 164:252-258

22. Pitkaranta A, Virolainen A, Jero J, Arruda E, Hayden FG. Detection of rhinovirus, respiratory syncytial virus, and coronavirus infections in acute otitis media by reverse transcriptase polymerase chain reaction. Pediatrics 1998;102:291-295.

23. Pitkaranta A, Jero J, Arruda E, Virolainen A, Hayden FG Polymerase chain reaction-based detection of rhinovirus, respiratory syncytial virus, and coronavirus in otitis media with effusion. J Pediatr 1998;133:390-394.

24. Rakes JP, Arruda E, Ingram JM, Hoover GE, Zambrano JC, Hayden FG, Platts-Mills TA, Heymann PW. Rhinovirus and respiratory syncytial virus in wheezing children requiring emergency care. IgE and eosinophil analyses. Am J Respir Crit Care Med 1999;159:785-790.

25. Henderson FW, Clyde WA, Collier AM, Denny FW. The etiologic and epidemiologic spectrum of bronchiolitis in pediatric practice. J Pediatr 1979;95:183-190.

26. Ray CG, Minnich LL, Holberg CJ, Shehab ZM, Wright AL, Barton LL, Taussig LM. Respiratory syncytial virus-associated lower respiratory illnesses: possible influence of other agents. The Group Health Medical Associates. Pediatr Infect Dis J 1993;12: $15-19$.

27. Saijo M, Terunuma H, Mizuta K, Mpabalwani EM, Monze M, Oshitani H, Luo N, Suzuki H, Numazaki Y. Respiratory syncytial virus infection in children with acute respiratory infections in Zambia. Epidemiol Infect 1998;121:397-400.

28. Jamjoom GA, al-Semrani AM, Board A, al-Frayh AR, Artz F, alMobaireek KF. Respiratory syncytial virus infection in young children hospitalized with respiratory illness in Riyadh. J Trop Pediatr 1993;39:346-349.

29. Chew FT, Doraisingham S, Ling AE, Kumarasinghe G, Lee BW. Seasonal trends of viral respiratory tract infections in the tropics. Epidemiol Infect 1998;121:121-128. 
30. Bakir TMF, Halawani M, Ramia S. Viral aetiology and epidemiology of acute respiratory infections in hospitalized Saudi children. J Trop Pediatr 1998;44:100-103.

31. Jain A, Pande A, Misra K, Mathuri A, Chaturvedi UC. An Indian hospital study of viral causes of acute respiratory infection in children. J Med Microbiol 1991;35:219-223.

32. Lina B, Valete M, Foray S, Luciani J, Stagnara J, See DM, Aymard M. Surveillance of community-acquired viral infections due to respiratory viruses in Rhone-Alpes (France) during winter 1994-1995. J Clin Microbiol 1996;34:3007-3011.

33. Savy V, Baumeister E, Bori F, Shiroma M, Campos A. Evaluacion etiologica y clinica de infecciones respiratorias agudas bajas en uma población infantil. Medicina (B Aires) 1996;56:213-217.

34. Ramos EAG, Freitas-Souza LS, Ribeiro DHA, Guedes HTV, Costa Filho LA, Santiago CMG, Oliva LC, Jesus CC. Diagnóstico de infecções respiratórias agudas virais em Salvador. Anais do XXXI Congresso da Sociedade Brasileira de Medicina Tropical. São Paulo, 31 março 1995. Rev Soc Bras Med Trop 1995;28:188.

35. Ramos EAG, Freitas-Souza LS, Ribeiro DHA, Guedes HTV, Ramos NMGS, Costa Filho LA, Santiago CMG, Jesus CC, Carvalho MAS, Oliveira JP, Velloso LF, Sampaio GF. Acute respiratory infection associated with respiratory syncytial virus (RSV) in children from Salvador-Bahia. Anais do VIII Encontro Nacional de Virologia (Sociedade Brasileira de Virologia) São Lourenço, 27 novembro 1996.

36. Straliotto SM. Prevalência de vírus respiratórios em pacientes pediátricos. Master's Degree thesis. Porto Alegre: Fundação Faculdade de Ciências Médicas e Irmandade da Santa Casa de Misericórdia, Porto Alegre-Brasil; 1995, 105 p.

37. Sutmoller F, Ferro ZP, Asensi MD, Ferreira V, Mazzei IS, Cunha BL. Etiology of acute respiratory tract infections among children in a combined community and hospital study in Rio de Janeiro. Clin Infect Dis 1995;20:854-860.

38. Miyao CR, Gilio AE, Vieira S, Hein N, Pahl MMC, Betta SL, Durigon EL, Stewein KE, Queiroz DAO, Botosso VF, Gomes MCS, Lopes CLBC, Ejzenberg B, OKAY Y. Infecções virais em crianças internadas por doença do trato respiratório inferior. J Pediatria 1999;75:334-344.

39. Nascimento JP, Siqueira MM, Sutmoller F, Krawczuk MM, de Farias V, Ferreira V, Rodrigues MJ. Longitudinal study of acute respiratory disease in Rio de Janeiro: occurrence of respiratory viruses during four consecutive years. Rev Inst Med Trop Sao Paulo 1991;33:287-296.

40. Silva RECF. Contribuição ao estudo epidemiológico do vírus sincicial respiratório na região metropolitana de Vitória-ESBrasil. Thesis, Master's Degree. Vitória, Brazil: Universidade Federal do Espírito Santo, Vitória—Brasil. 1999, 99 p.

41. Mello WA, Pinheiro EP. Viroses respiratórias. Belém: Fundação de Serviços de Saúde Pública, Instituto Evandro Chagas; 1986. p 473-481.

42. Mello WA, Alves JER Jr, Carneiro FEV, Magalhães JMPE, Fernandes EA. Viral respiratory infections in children of Boa Vista, Roraima, Brazil. In: Encontro Nacional de Virologia, 1999; and Encontro de Virologia do Mercosul, 1999. Resumos. $131 \mathrm{p}$.

43. Hein N. Aspectos epidemiológicos da infecção por vírus sincicial respiratório em crianças internadas. Thesis, Master's Degree. São Paulo: Faculdade de Medicina, Universidade de São PauloBrasil; 1997. $100 \mathrm{p}$.

44. Cruz CR. Virus respiratório sincicial em lactentes internados com infecção aguda do trato respiratório inferior. Thesis, Master's Degree. Curitiba, Brazil: Universidade Federal do Paraná, Curitiba-Brasil. 1998, 138 p.

45. Papadopoulos NG, Bates PJ, Bardin PG, Papi A, Leir SH, Fraenkel DJ, Meyer J, Lackie PM, Sanderson G, Holgate ST, Johnston SL. Rhinovirus infects the lower airways. J Infect Dis 2000; $181: 1875-1884$

46. Johnston SL. The role of viral and atypical bacterial pathogens in asthma pathogenesis. Pediatr Pulmonol [Suppl] 1999;18:141143.

47. Douglass JA, O'Hehir RE. What determines asthma phenotype? Respiratory infections and asthma. Am J Respir Crit Care Med 2000;161:211-214. 